\title{
Controlled inpatient study of tienilic acid in treatment of gout and hypertension
}

\author{
J. A. REARDON AND J.T. SCOTT
}

From the Kennedy Institute of Rheumatology, London W6, and Charing Cross Hospital, London W6.

SUMMARY Under inpatient controlled conditions 4 patients with gout and hypertension were treated with varying doses of tienilic acid, a new uricosuric diuretic. Plasma urate levels were reduced by an average of $50 \%$ in association with significantly increased urinary urate excretion. A twicedaily regimen was considerably more effective than a single morning dosage in reduction of plasma urate, though both regimens were equally effective in antihypertensive potency. The single daily regimen produced greater diurnal fluctuations in plasma urate and was more frequently associated with the development of acute gout attacks.

Attention has previously been drawn to the unusually high prevalence of hypertension among patients with gout. ${ }^{1-5}$ While a diastolic blood pressure of $90 \mathrm{mmHg}$ or greater is found in approximately $21 \%$ of a similar nongouty population (males, aged 25-65), up to $50 \%$ of patients with gout will be so affected. ${ }^{6}$ Thiazide diuretics, a group of drugs commonly used for hypertension, elevate the serum uric acid level by virtue of their urate-retaining action. ${ }^{7}$ Control of hyperuricaemia and gout is thereby made more difficult requiring a large dose of urate-lowering drugs. In other patients, with hypertension alone, the effect of the thiazides may be to raise the serum level of uric acid and perhaps to precipitate an acute gout attack. ${ }^{8}$

A new diuretic, tienilic acid, has been reported to lower serum uric acid levels by increasing urinary excretion. ${ }^{910}$ Since these reports have been confined to primarily hypertensive patients, usually without hyperuricaemia, it was decided to investigate the drug in patients with previously diagnosed hyperuricaemia and gout as well as hypertension and to assess the potential for control of both conditions with a single agent.

\section{Patients and methods}

Four patients were admitted to hospital and maintained on a low-purine diet for the duration of the study. All were hyperuricaemic, and gouty arthritis had been previously diagnosed on generally accept-

Accepted for publication 25 January 1980. able clinical grounds; hypertension (resting diastolic blood pressure $90 \mathrm{mmHg}$ or greater) was confirmed on at least 3 occasions before admission. Throughout admission, resting and standing blood pressures were measured 4-hourly (except at $2 \mathrm{am}$ ). Estimations of uric acid levels were performed by a uricase method on plasma (8-hourly) and urine (4-hourly collections, except midnight to $8 \mathrm{am}$ ). Creatinine clearance, liver function tests, fasting cholesterol and triglycerides, full blood count, and erythrocyte sedimentation rate (ESR) were performed before and at the end of each admission.

Chest $x$-ray and electrocardiography (ECG) were carried out before beginning treatment. Serum electrolytes were measured frequently and total urinary electrolytes daily. Blood pressure and plasma and urine uric acid were monitored for several days, (average 6) following admission, until these were stabilised with bed-rest and the lowpurine diet. Treatment with tienilic acid was then begun according to the following regimen:

$\begin{array}{ll}\text { Days } 1,2,3 & 125 \mathrm{mg} 8 \mathrm{am} \\ \text { Days 4, 5, } & 125 \mathrm{mg} 8 \mathrm{am} \text { and } 4 \mathrm{pm}(125 \mathrm{mg} \text { b.i.d.) } \\ \text { Days 7,8,9 } & 250 \mathrm{mg} 8 \mathrm{am} \\ \text { Days 10,11, 12 } & 250 \mathrm{mg} 8 \mathrm{am} \text { and } 4 \mathrm{pm}(250 \mathrm{mg} \text { b.i.d.) } \\ \text { Days 13,14,15 } & 500 \mathrm{mg} 8 \mathrm{am}\end{array}$

Indomethacin was given as required for treatment of acute gout, but was not prescribed prophylactically. All patients gave informed consent.

\section{Results}

PLASMA URIC ACID

Changes produced by different dosage regimens can 
be seen in Tables 1 and 2 and Fig. 1. In Table 1 levels have been measured at 8 am each day prior to any medication that day. In Table 2 samples have been drawn at $8 \mathrm{am}$, noon, $4 \mathrm{pm}, 8 \mathrm{pm}$, and 12 midnight on the third day of each dosage regimen, and then at 8 am the following morning, before each regimen alteration. The levels at the times when dosage regimens change (that is, 8 am on days $4,7,10$, and 13) are plotted in Fig. 1, expressed as the percentage alterations from the pretreatment level. Statistical comparisons at these change-over points are shown in Table 3.

\section{URINARY URIC ACID}

Table 4 shows average uric acid excretion for each 3-day dosage regimen, while in Fig. 2 the excretion in each 4-hourly period has been averaged for the 4 patients (a total of 12 values over the 3 days of each dosage regimen), and plotted cumulatively to show the excretion rate through 24 hours.

Table 1 Mean plasma uric acid (8 am)

\begin{tabular}{rlll}
\hline Day & \multicolumn{2}{l}{ Tienilic acid dose $(\mathrm{mg})$} & $\begin{array}{l}\text { Plasma uric } \\
\text { acid }(\mu \mathrm{mol} / \mathrm{l})\end{array}$ \\
\cline { 2 - 3 } & 8 am & $4 \mathrm{pm}$ & \\
\hline 1 & 125 & $\mathrm{Nil}$ & 516 \\
2 & 125 & $\mathrm{Nil}$ & 492 \\
3 & 125 & $\mathrm{Nil}$ & 486 \\
4 & 125 & 125 & 474 \\
5 & 125 & 125 & 372 \\
6 & 125 & 125 & 318 \\
7 & 250 & $\mathrm{Nil}$ & 348 \\
8 & 250 & $\mathrm{Nil}$ & 348 \\
9 & 250 & $\mathrm{Nil}$ & 354 \\
10 & 250 & 250 & 336 \\
11 & 250 & 250 & 264 \\
12 & 250 & 250 & 246 \\
13 & 500 & $\mathrm{Nil}$ & 240 \\
14 & 500 & $\mathrm{Nil}$ & 270 \\
15 & 500 & Nil & 282 \\
16 & Discharge & - & 306 \\
\hline
\end{tabular}

Serum Urate : Alteration with Tienilic Acid

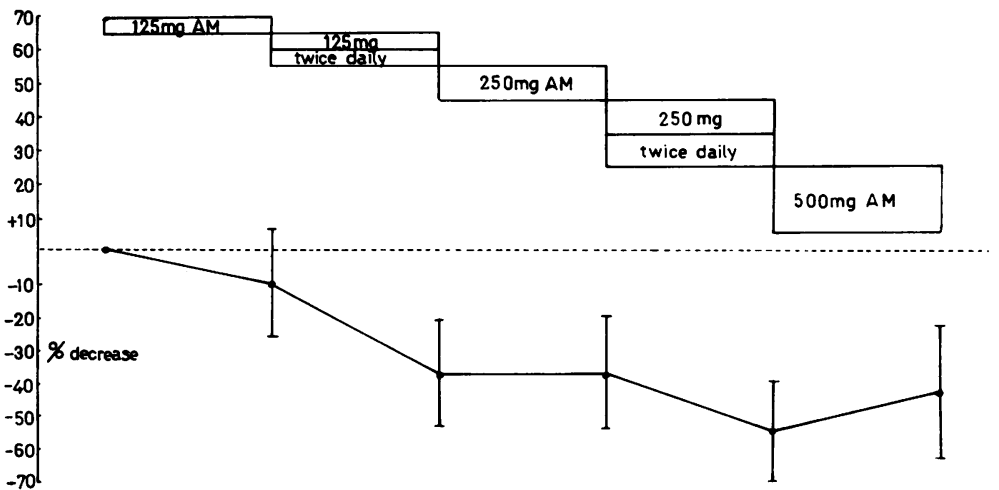

Fig. 1 Percentage alteration in plasma uric acid level at times of alteration in dosage regimen.

URATE CLEARANCE

Since the serum uric acid fluctuated considerably over each 3-day dosage regimen, the clearance was calculated in each case by averaging the 5 samples

Table 2 Mean plasma uric acid: diurnal variation with tienilic acid ( $\mu \mathrm{mol} / \mathrm{l})$

\begin{tabular}{|c|c|c|c|c|c|c|}
\hline Dosage regimen & $\begin{array}{l}0800 \\
8 \mathrm{am}\end{array}$ & $\begin{array}{l}1200 \\
\text { Noon }\end{array}$ & $\begin{array}{l}1600 \\
4 \mathrm{pm}\end{array}$ & $\begin{array}{l}2000 \\
8 \text { pm }\end{array}$ & $\begin{array}{l}2400 \\
\text { Mid- } \\
\text { night }\end{array}$ & $\begin{array}{l}0800 \\
8 \mathrm{am}\end{array}$ \\
\hline $\begin{array}{l}125 \mathrm{mg} 8 \mathrm{am} \\
125 \mathrm{mg} 8 \mathrm{am}, 4 \mathrm{pm} \\
250 \mathrm{mg} 8 \mathrm{am} \\
250 \mathrm{mg} 8 \mathrm{am}, 4 \mathrm{pm} \\
500 \mathrm{mg} 8 \mathrm{am}\end{array}$ & $\begin{array}{l}486 \\
318 \\
354 \\
246 \\
282\end{array}$ & $\begin{array}{l}414 \\
312 \\
306 \\
210 \\
252\end{array}$ & $\begin{array}{l}402 \\
288 \\
282 \\
216 \\
234\end{array}$ & $\begin{array}{l}396 \\
258 \\
264 \\
204 \\
252\end{array}$ & $\begin{array}{l}408 \\
258 \\
270 \\
204 \\
282\end{array}$ & $\begin{array}{l}474 \\
348 \\
336 \\
240 \\
306\end{array}$ \\
\hline
\end{tabular}

Table 3 Tienilic acid: statistical comparison* of different regimens

\begin{tabular}{llll}
\hline Regimens compared & $\begin{array}{l}\text { Decrease in } \\
\text { plasma } \\
\text { uric acid }\end{array}$ & $\begin{array}{l}\text { Increase in } \\
\text { urinary } \\
\text { uric acid }\end{array}$ & $\begin{array}{l}\text { Increase in } \\
\text { clearance } \\
\text { uric acid }\end{array}$ \\
\hline $125 \mathrm{mg}$ am Nil & $\mathrm{NS}$ & $\mathrm{NS}$ & $\mathrm{NS}$ \\
$125 \mathrm{mg}$ b.i.d. Nil & $<0.001$ & $<0.001$ & $<0.005$ \\
$250 \mathrm{mg}$ am Nil & $<0.05$ & $<0.01$ & $<0.05$ \\
$250 \mathrm{mg}$ b.i.d. Nil & $<0.001$ & $<0.01$ & $<0.005$ \\
$500 \mathrm{mg}$ am Nil & $<0.005$ & $<0.05$ & $<0.05$ \\
$125 \mathrm{mg}$ b.i.d. $125 \mathrm{mg}$ am & $<0.0005$ & $<0.005$ & $<0.0005$ \\
$125 \mathrm{mg}$ b.i.d. $250 \mathrm{mg}$ am & $\mathrm{NS}$ & $<0.005$ & $<0.05$ \\
$250 \mathrm{mg}$ b.i.d. $250 \mathrm{mg}$ am & $<0.0005$ & $<0.05$ & $<0.0005$ \\
$250 \mathrm{mg}$ b.i.d. $125 \mathrm{mg}$ b.i.d. $<0.05$ & $\mathrm{NS}$ & $<0.001$ \\
$250 \mathrm{mg}$ b.i.d. $500 \mathrm{mg}$ am & $<0.05$ & $<0.05$ & $<0.05$ \\
\hline
\end{tabular}

Table 4 Urinary uric acid (mmol/24 hours)

\begin{tabular}{|c|c|c|c|c|c|c|}
\hline Patient & Nil & $\begin{array}{l}125 \mathrm{mg} \\
\mathrm{am}\end{array}$ & $\begin{array}{l}125 \mathrm{mg} \\
\text { b.i.d. }\end{array}$ & $\begin{array}{l}250 \mathrm{mg} \\
\mathrm{am}\end{array}$ & $\begin{array}{l}250 \mathrm{mg} \\
\text { b.i.d. }\end{array}$ & $\begin{array}{l}500 \mathrm{mg} \\
\mathrm{am}\end{array}$ \\
\hline $\begin{array}{l}1 \\
2 \\
3 \\
4 \\
\text { Average }\end{array}$ & $\begin{array}{l}4 \cdot 0 \\
3 \cdot 1 \\
3 \cdot 7 \\
2 \cdot 3 \\
3 \cdot 3\end{array}$ & $\begin{array}{l}3 \cdot 6 \\
4 \cdot 3 \\
5 \cdot 7 \\
3 \cdot 8 \\
4 \cdot 3\end{array}$ & $\begin{array}{l}5 \cdot 4 \\
5 \cdot 2 \\
6 \cdot 0 \\
3 \cdot 9 \\
5 \cdot 1\end{array}$ & $\begin{array}{l}4 \cdot 5 \\
4 \cdot 6 \\
4 \cdot 5 \\
3 \cdot 1 \\
4 \cdot 2\end{array}$ & $\begin{array}{l}6 \cdot 2 \\
6 \cdot 3 \\
7 \cdot 0 \\
3 \cdot 4 \\
5 \cdot 7\end{array}$ & $\begin{array}{l}4 \cdot 4 \\
4 \cdot 4 \\
6 \cdot 2 \\
3 \cdot 0 \\
4 \cdot 5\end{array}$ \\
\hline
\end{tabular}




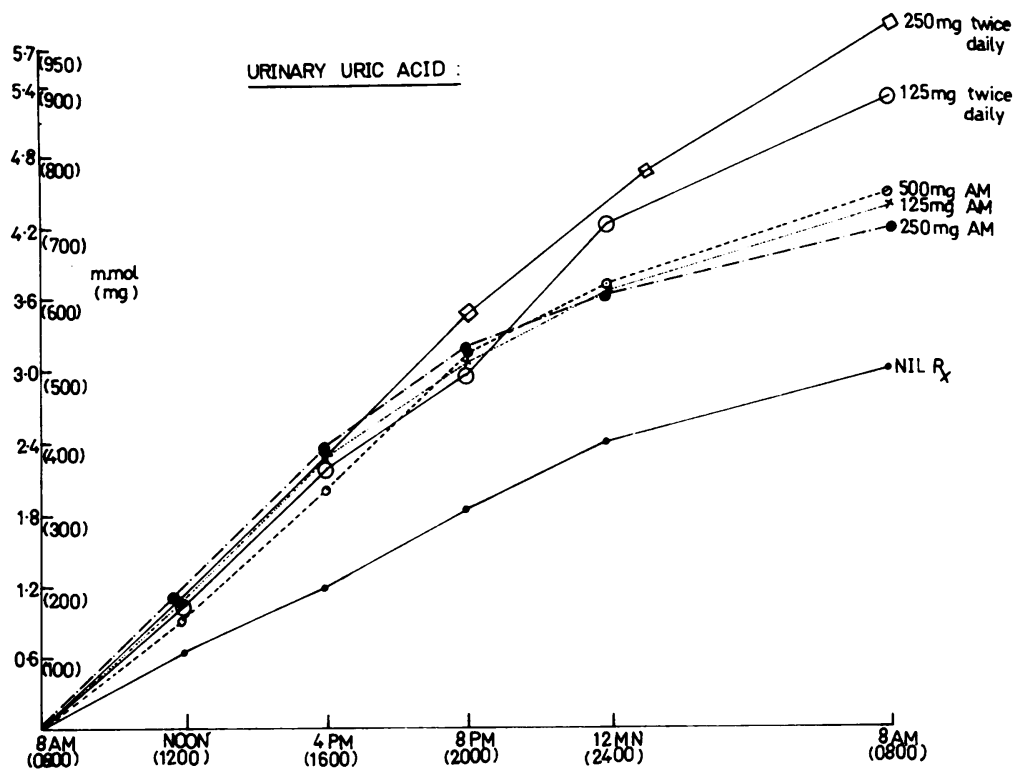

Fig. 2 Urinary uric acid measured 4-hourly, and plotted cumulatively to show excretion rates through 24 hours.

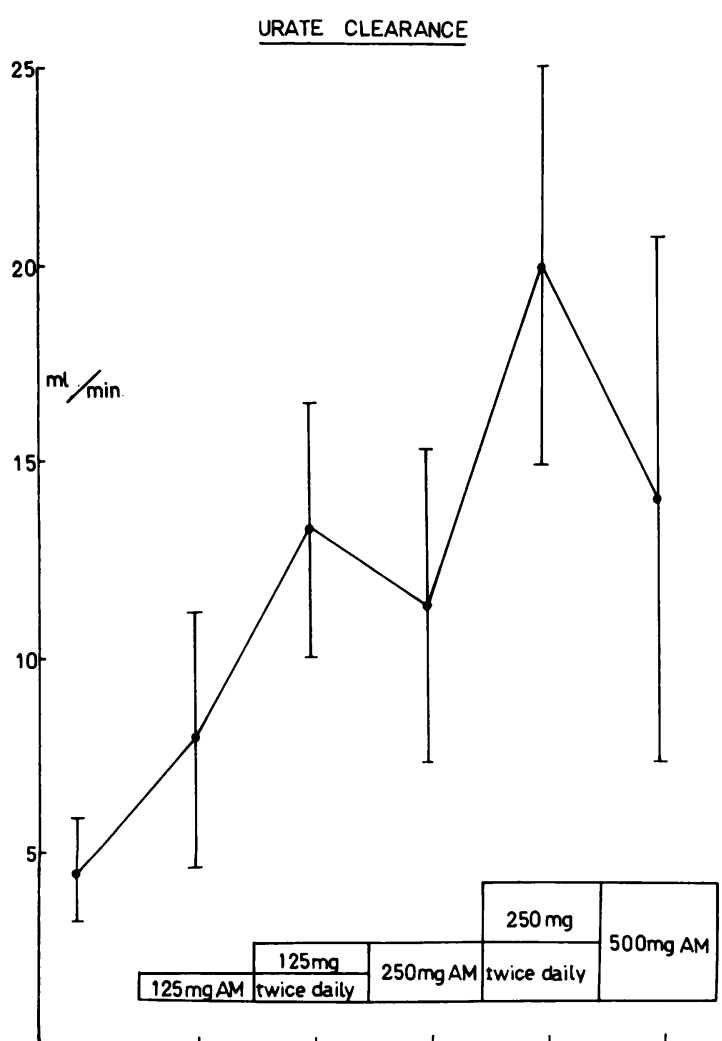

Fig. 3 Uric acid clearance, calculated on the third day of each dosage regimen. taken on the final 24 hours of each treatment period (noon, 4 pm, 8 pm, 12 midnight, $8 \mathrm{am}$ ), and by using the 24-hour urine excretion on this 3rd day only. The results are shown in Fig. 3.

\section{BLOOD PRESSURE}

While values at 6 am were generally a little lower than those later in the day, it was felt that the 10 am reading more closely represented the average throughout the 24-hour period and would also allow more satisfactory follow-up after discharge, in that patients would attend the outpatient clinic at about this time of day. As can be seen from Fig. 4, reduction in systolic and diastolic pressures (resting) was seen with all dosage regimens, though the greatest average reduction was found with $250 \mathrm{mg}$ b.i.d. (158/104 to $139 / 91)$.

\section{FLUID BALANCE/URINARY ELECTROLYTES}

Fig. 5 shows the average fluid balance for the 4 patients for each day of treatment. Although a diuresis was evident with all treatment schedules, there appears a trend towards a more vigorous diuresis with the $250 \mathrm{mg}$ b.i.d. regimen. The same trend appears with 24-hour urinary potassium, but no obvious pattern appeared with urinary sodium.

SIDE EFFECTS

Hypokalaemia. Table 5 shows serum potassium levels before treatment and before discharge from hospital, this difference being significant $(P<0 \cdot 05)$.

Serum creatinine. Serum creatinine rose on average 


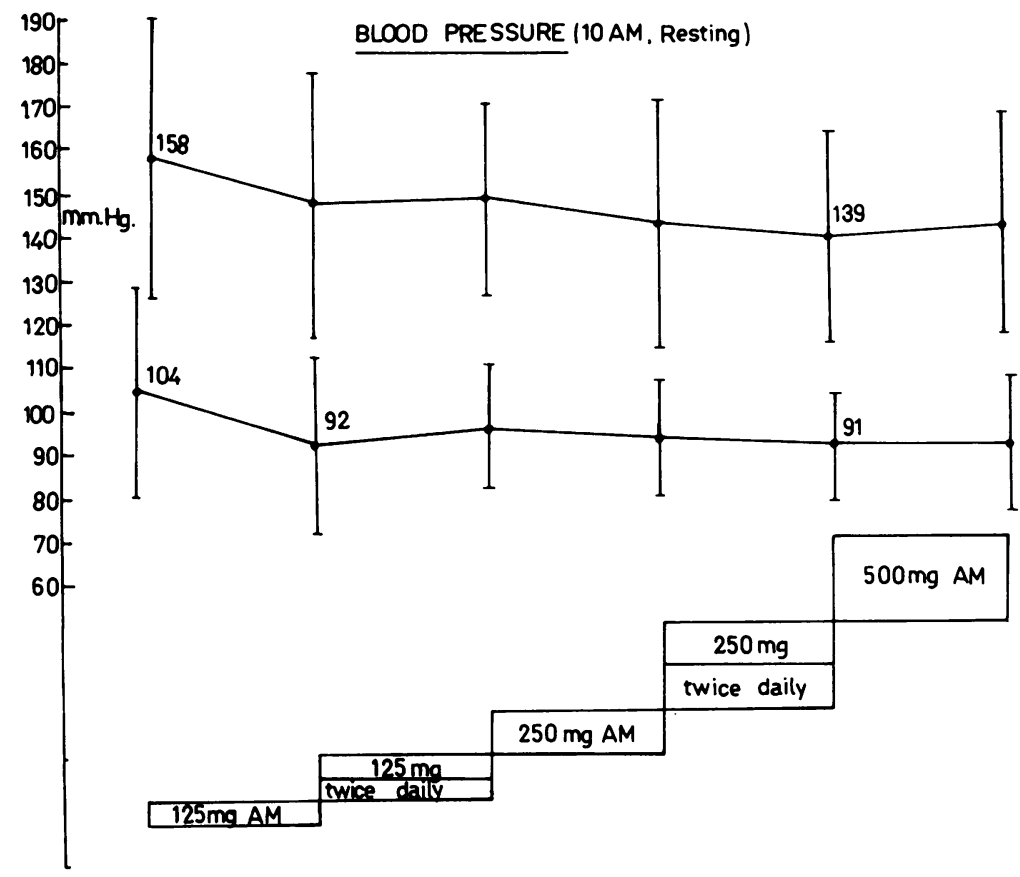

Fig. 4 Average blood pressure measurements at 10 am for each dosage regimen.

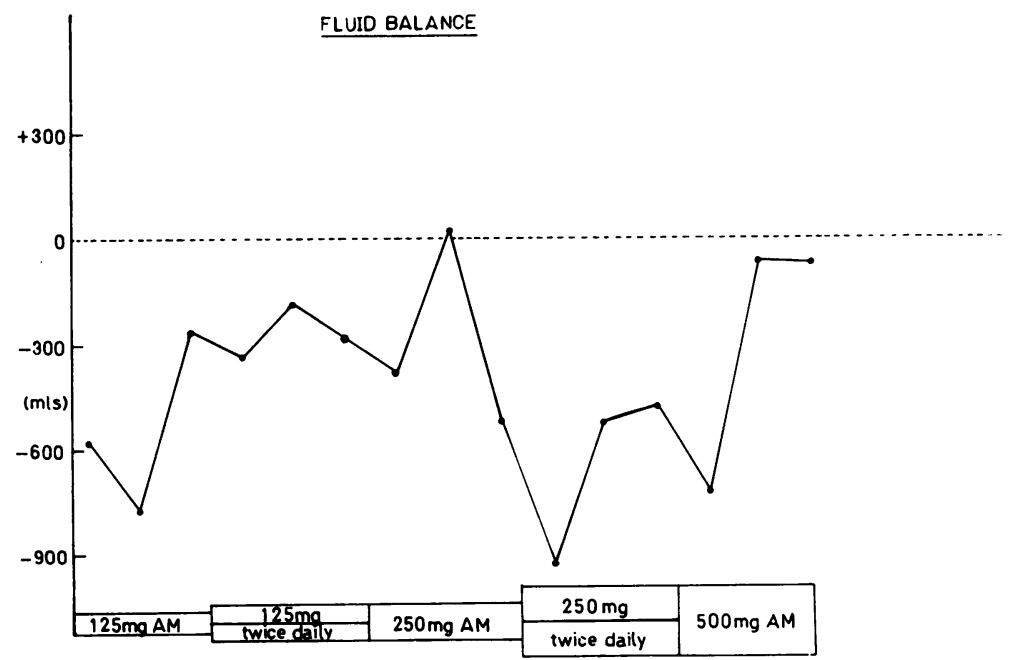

Fig. 5 Daily fluid balance measurements, expressed as average net gain or loss for each dosage regimen.

Table 5 Tienilic acid: serum potassium, renal function

\begin{tabular}{llllllr}
\hline Patient & \multicolumn{2}{l}{ Serum potassium $(\mathrm{mmol} / \mathrm{l})$} & \multicolumn{2}{l}{ Serum creatinine $(\mu \mathrm{mol} / \mathrm{l})$} & \multicolumn{2}{c}{ Creatinine clearance $(\mathrm{ml} / \mathrm{min})$} \\
\hline & Pre-treatment & Post-Treatment & Pre-treatment & Post-treatment & Pre-treatment & Post-treatment \\
\hline 1 & 3.0 & 2.9 & 119 & 159 & 120 & 54 \\
2 & 3.9 & 3.6 & 107 & 88 & 83 & 47 \\
3 & 3.7 & 3.0 & 78 & 181 & 90 & 74 \\
4 & 3.7 & 3.1 & 103 & 131 & 101 & 74 \\
Average & 3.6 & 3.1 & 103 & &
\end{tabular}




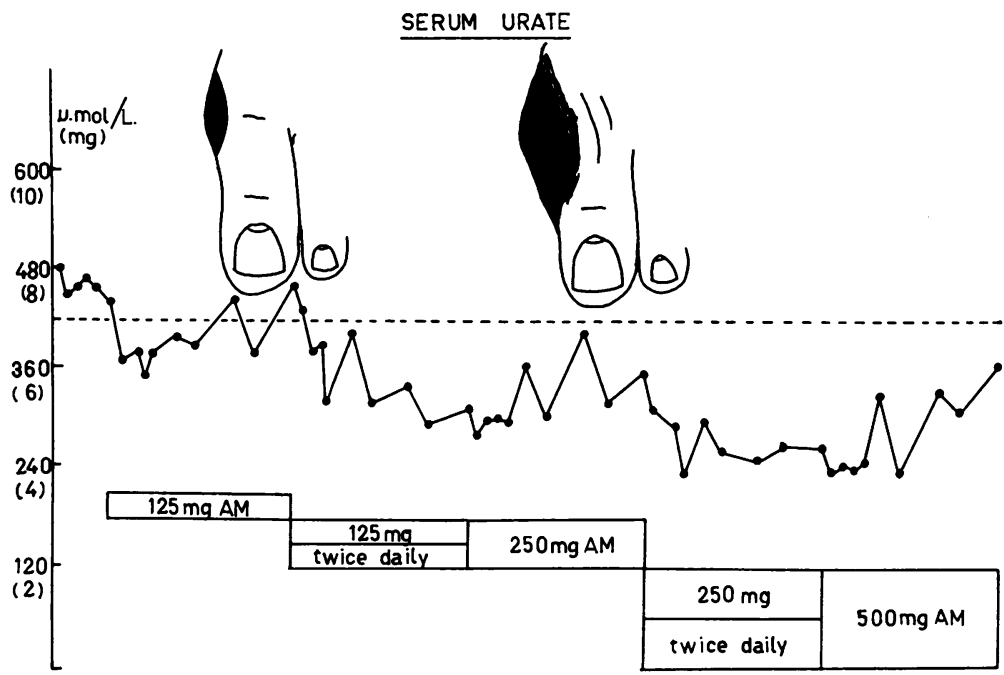

Fig. 6 Alteration in plasma urate with different dosage regimens, to show time of appearance of acute gout (patient 1 in Tables 4 and 5). by $28 \mu \mathrm{mol} / 1$ throughout the admission, and creatinine clearance fell by $27 \mathrm{ml} / \mathrm{min}$. There was, however, considerable variation among the 4 patients, and these differences did not reach statistical significance.

Acute gout. Acute attacks were seen in 3 of the 4 patients and required treatment with indomethacin. In 2 of these the onset appeared during a single daily dosage regimen. Fig. 6 illustrates the more striking example.

\section{Discussion}

These results with tienilic acid indicate the possibility of controlling hyperuricaemia, gout, and hypertension with a single agent. Although the number of patients was small, statistically significant reductions in serum uric acid and increased urinary uric acid excretion were consistently obtained. While there was an alteration from pretreatment values with single daily dosage, the urinary urate excretion was not increased with increased single morning dosage, even from $125 \mathrm{mg}$ to $500 \mathrm{mg}$. The serum uric acid levels are a little more difficult to compare in that the baseline level before each dosage regimen varied according to the effect achieved with the previous regimen. Best results were obtained with $250 \mathrm{mg}$ b.i.d. with the greatest plasma uric acid reduction and increase in urate clearance.

The reductions in systolic and diastolic blood pressure are of a similar order to those previously reported with thiazide diuretics. ${ }^{10}$ Trials comparing tienilic acid and various thiazides found no significant difference between the various agents. ${ }^{11} 12$

Side effects seen were those one might theoretically expect with an agent of this type. In common with the thiazides the drug reduces serum potassium, and 1 patient required potassium supplements. Serum creatinine levels varied considerably from patient to patient, with a trend towards an increase during hospital admission, associated with a fall in creatinine clearance. These values did, however, tend to revert to the pretreatment stage over the months following discharge while the patients continued to take the drug. Approximately 3 months after discharge, 1 patient, a severe overproducer of uric acid previously intolerant of other urate-lowering medications, including allopurinol, developed left iliac fossa discomfort with strangury, and was presumed to have passed a small calculus. The intravenous pyelogram at the time was completely normal.

Acute gout developed in 2 of the 4 patients, while a third, the overproducer mentioned above, had moderately severe gout attacks before as well as during treatment. These attacks tended to be associated with the greater diurnal fluctuations in serum urate produced by the single daily dose regimen. Their development is similar to the appearance of acute attacks in the initial periods after starting treatment with probenecid, allopurinol, or other urate-lowering drugs. ${ }^{13-15}$

The short duration of this study and the small numbers involved make it impossible to state that the drug will ultimately prevent further attacks of gout, but serum urate levels in all 4 patients have remained remarkably consistent over the months following discharge. In comparison with the average pretreatment level of $8.6 \mathrm{mg}$ per $100 \mathrm{ml}(516 \mu \mathrm{mol} / \mathrm{l})$, the average level was $4.0 \mathrm{mg}$ per $100 \mathrm{ml}(240$ 


\section{Reardon, Scott}

$\mu \mathrm{mol} / \mathrm{l}) 3$ months after discharge, on $250 \mathrm{mg}$ twice daily in 3 patients and $500 \mathrm{mg}$ twice daily in 1 (no dietary restriction).

The following conclusions may be drawn. Tienilic acid is an effective uricosuric agent in patients with gout; the magnitude of this effect is considerably greater in a twice daily than a single daily dosage. Raised serum uric acid levels in patients with gout were reduced to normal, with an average reduction of $50 \%$ from the pretreatment value with $250 \mathrm{mg}$ twice daily. Similar antihypertensive action was seen with all dosages used. The development of acute gout attacks appeared to reflect fluctuating serum uric acid levels, seen more with single daily dosage. Tienilic acid offers the potential for control of commonly associated hyperuricaemia, gout, and hypertension with a single agent.

ADDENDUM: During the course of publication tienilic acid was withdrawn from further use in the United States, where it had been freely available on prescription, because of reports of hepatotoxicity. It has also been withdrawn from clinical trials in Great Britain, although it continues to be prescribed on the Continent. No abnormalities of liver function tests were seen in this study.

\section{References}

1 Ogryzlo M A. Visceral (non-articular) manifestations associated with gout. Clin Orthop 1970; 71 : 46.

2 Weiss T E, Segaloff A, Moore C. Gout and diabetes. Metabolism 1957; 6: 103.

3 Grahame R, Scott J T. Clinical survey of 354 patients with gout. Ann Rheum Dis 1970; 29: 461-8.
4 Gutman A B, Yü T F. Uric acid metabolism in normal man and primary gout. $N$ Engl $J$ Med 1965; 273: 253.

${ }^{5}$ Kuzell W C, Schaffarzich R W, Naugler W E, et al. Some observations on 520 gouty patients. J Chron Dis 1955; 2 : 645-69.

6 Hamilton M, Pickering G W, Roberts J A F, Sowerby G S C The aetiology of essential hypertension. 1 . The arterial pressure in the general population. Clin Sci 1954; 13: 11-35.

7 Steele T H, Oppenheimer S. Factors affecting urate secretion following diuretic administration in man. Am J Med 1969; 47: 564-74.

8 Aronoff A. Acute gouty arthritis precipitated by cholorothiazide. $N$ Engl J Med 1960; 262: 767.

9 Stote R M, Chenill D A, Erb B B, et al. Site of action of SKF62698, a new diuretic-uricosuric agent. Clin Res 1974; 22: 721A.

10 Frolich E D, De Carrealho J G R, Dunn F G, Chrysant S G. Antihypertensive and renal effects of tienilic acid. Postgrad Med J 1979; 55: Suppl. 3, 98-102.

11 Bolli P, Simpson F O, Waal-Manning H J. Comparison of tienilic acid with cyclopenthiazide in hyperuricaemic hypertensive patients. Lancet 1978; ii: 595-98.

12 Carvalho J G R, Dunn F, Chrysant S G, Frolich E D. Ticrynafen, a novel uricosuric antihypertensive natriuretic agent. Arch Intern Med. 1978; 138: 53-7.

13 Yü T F, Gutman A B. Effect of allopurinol (4-hydroxypyrazolo $(3,4-d)$ pyramidine) on serum and urinary uric acid in primary and secondary gout. Am J Med 1964; 37: 885-98.

14 de Seze S, Rychewaert A, D'Anglejan G. The treatment of gout by probenecid (a study based on 156 cases, 68 of which were treated from 1 to 9 years). Rev Rhum Mal Osteoartic 1963; 30: 93-102.

15 Massbernard A, Guilbaud J, Drouiou J. Clinical experiences with long term treatment of gout with iodine and bromide derivatives of benzofuranes. Lyon Med $1971 ; 225$ : 683 